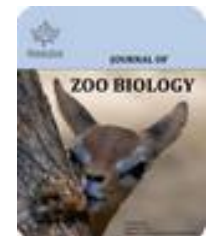

Available Online at EScience Press

Journal of Zoo Biology

ISSN: 2706-9761 (Online), 2706-9753 (Print)

https://esciencepress.net/journals/JZB

\title{
Changes in Serum Biochemistry of Fish, Catla catla in Response to Metal Toxicity
}

\begin{abstract}
aWardah Hassan*, bSajid Abdullah, cNaila Hadayat, dHuma Naz, eShakeela Parveen
a Department of Zoology, University of Sargodha, Sargodha, Pakistan.

${ }^{b}$ Department of Zoology, Wildlife and Fisheries, University of Agriculture, Faisalabad, Pakistan.

${ }^{c}$ Department of Botany, University of Okara, Okara, Pakistan.

d Department of Zoology, Cholistan University of Veterinary and Animal Sciences, Bahawalpur, Pakistan.

e Department of Zoology, Government Sadiq College Women University, Bahawalpur, Pakistan.
\end{abstract}

\section{ART I C L E I N F O}

\section{Article History}

Received: March 12, 2020

Revised: July 27, 2020

Accepted: October 19, 2020

\section{Keywords}

Pollutants

Fish

Biochemical Parameters
A B S T R A C T

In the present study an attempt has been made to evaluate the effect of heavy metals i.e. nickel (Ni) and zinc ( $\mathrm{Zn}$ ) on the serum biochemical parameters of Catla catla. The fish were exposed to lethal concentrations (96-hr LC50) of selected metals. The studied serum biochemical parameters were sodium $(\mathrm{Na})$, potassium $(\mathrm{K})$, chloride $(\mathrm{Cl})$, albumin (Alb), urea (U), glucose (Glu), aspartate aminotransferase (Ast) and alanine aminotransferase (Alt). Results revealed a decrease in $\mathrm{Na}, \mathrm{Cl}$ and Alb levels of metal exposed fish at all exposure periods as compared to control. However, an increase in K, U, Glu, Ast and Alt levels was observed in the metal exposed fish. All the biochemical parameters showed significant dependence on exposure durations in both treated fish except $\mathrm{Na}$ and Alb in $\mathrm{Zn}$ treated fish. This study indicated that the alterations in serum biochemical parameters may be the result of the target tissue damage and dysfunction induced by the metal and that these parameters can thus be used to assess the toxic effects of metals on organisms.

*Corresponding Author: Wardah Hassan

Email: wardahhassan1@hotmail.com Tel: +92-331-4642002

(C) The Author(s) 2020.

\section{INTRODUCTION}

Freshwater is highly susceptible to pollution since it acts as a direct sink for the consequences of anthropogenic activities which are always accompanied with the danger of criminal negligence or accidental discharges (Sachar and Raina, 2014). The discharge of domestic, industrial and urban wastes produced through human activities into aquatic environments usually causes stress to aquatic organisms (Palanisamy et al., 2011). Heavy metals constitute a major group of aquatic contaminants and their large amount accumulates in aquatic ecosystems as a consequence of land-based activities (Vutukuru, 2003). Metals are of particular concern due to their non-degradable and persistent nature therefore could cause negative effects to the inhabiting fauna and flora (Javed et al., 2016).
Nickel ( $\mathrm{Ni}$ ) is an essential element at low concentration for living organisms but it is highly toxic at higher concentration (Magyarosy et al., 2002). It is released by industries that use $\mathrm{Ni}$, convert scrap or new $\mathrm{Ni}$ into $\mathrm{Ni}$ compounds or alloys and during Ni mining. These industries may also release $\mathrm{Ni}$ in wastewater (Al-Attar, 2007). Recently, several reports are available regarding the $\mathrm{Ni}$ toxicity in different animal species, particularly fish (Doreswamy et al., 2004; Gupta et al., 2006; Hoang et al., 2004).

Zinc (Zn), as an essential micronutrient, is required in small quantities for normal development and metabolism of organisms and is important for various physiological processes of cells (Varin et al., 2008). If its level exceeds the physiological requirements, it can act as a toxicant. The common anthropogenic sources of $\mathrm{Zn}$ are galvanized iron work and $\mathrm{ZnCl}_{2}$ used in plumbing and paints. Zinc 
wastes cause direct toxicity to aquatic organisms at augmented waterborne levels (Niyogi and Wood, 2006). The animals flourishing in water bodies are exposed to extraordinarily high levels of contaminants. Fishes are the animals that cannot escape from the negative effects of these contaminants and prove as good bio-indicators of aquatic pollution (N. and C., 2010). Measurement of serum biochemical parameters is valuable to ascertain the toxicity of target organs along with the overall health status of animals and provides initial warning of potentially detrimental alterations in stressed organisms (Jacobson-Kram and Keller, 2001). Alterations in serum enzyme activities are linked to the physiological changes in metal exposed fish (Kori-Siakpere et al., 2010).

Metals exposure to fish may cause variability in plasma ions level and ions regulatory disruption which may be used for computing toxic effects of metals. Serum protein, the majority of serum proteins which are produced in the liver, is used as an indicator of liver injury (Bernet et al., 2001). Studies have revealed that metals can cause either increase or of toxicant, length of exposure, water quality and fish species (Jee et al., 2005). Thus, the current study was aimed to examine the effects of $\mathrm{Ni}$ and $\mathrm{Zn}$ on the serum biochemical parameters of Catla catla.

\section{MATERIALS AND METHODS}

An experiment was conducted in the wet laboratory of Fisheries Research Farms, Department of Zoology, Wildlife and Fisheries, University of Agriculture, Faisalabad. Catla catla of desired weight (30 g) were obtained from the Fish Seed Hatchery, Faisalabad. They were brought to the wet laboratory and acclimatized to the laboratory conditions for 14 days. Pure chloride compounds of metals viz. nickel $\left(\mathrm{NiCl}_{2}\right.$. $\left.6 \mathrm{H} 2 \mathrm{O}\right)$ and zinc $\left(\mathrm{ZnCl}_{2}\right.$. 2H2O) were used in this experiment. Metals were dissolved into deionized water and stock solutions were prepared for required metals dilutions. The stock solutions were diluted to make required concentrations of metallic ions. Fish were exposed for 96-hr to waterborne lethal concentrations ( $\mathrm{LC}_{50}$ ) of metals which are already determined by (Kousar, 2014). The water temperature (30?C), pH (7) and total hardness (225 $\mathrm{mg} / \mathrm{L}$ ) of the test media were kept constant. Total ammonia, magnesium, carbon dioxide and calcium contents of the test media were monitored on daily basis by following the methods of (Association, 2013).

Blood samples for serum biochemical analysis were collected without an anticoagulant. Serum was obtained by centrifugation of blood at $3000 \mathrm{rpm}$ for 10 minutes. Samples were stored at $-80{ }^{\circ} \mathrm{C}$ before the further analysis. Serum biochemical parameters (sodium, potassium, chloride, albumin, urea, glucose, aspartate aminotransferase and alanine aminotransferase) were estimated following standard methods using commercially available kits by BioMed Company. Data were reported as mean \pm S.D. Significance of samples means $(\mathrm{p}<0.05)$ between control and metals exposed fish were measured using Sudent's ttest by SPSS. The treatment-wise data were subjected to step-wise regression to see the probable impacts of exposure durations on biochemical parameters.

\section{RESULTS}

The results of present study showed some differences in the values of serum biochemical parameters of control and metal contaminated $C$. catla. It was noted that the level of $\mathrm{Na}$ in fish exposed to metals ( $\mathrm{Ni}$ and $\mathrm{Zn}$ ) was reduced at all exposure periods as compared to control. The comparative decrease in $\mathrm{Na}$ level of metals exposed fish from control was significant at the end of all exposure durations except 24-hr exposure. Potassium ions in serum of treated fish differed significantly from control fish at all exposure durations except at the end of 24-hr exposure. Chloride level in the fish exposed to either $\mathrm{Ni}$ or $\mathrm{Zn}$ was significantly decreased after 74 and 96-hr exposure as compared to control while it was non-significant after 24 and 48-hr of exposure. In present study the Alb content in fish exposed to metals decreased at all exposure periods as compared to control. The comparative decrease in Alb contents of metals exposed fish from control was significant at the end of all exposure durations. Higher urea and glucose level was observed in metals exposed fish than the control. Significant differences in glucose and urea levels were recorded in fishes exposed to metals as compared to control for different exposure durations. Increase in aspartate aminotransferase and alanine aminotransferase levels was recorded in both $\mathrm{Ni}$ and $\mathrm{Zn}$ exposed fish as compared to control.

The differences in the levels of aspartate aminotransferase and alanine aminotransferase of fish exposed to different treatments were statistically significant (Table 1). Ionic serum biochemical parameters i.e. $\mathrm{Na}, \mathrm{K}$ and $\mathrm{Cl}$ level in $\mathrm{Ni}$ exposed fish showed significant $(\mathrm{P}<0.05)$ dependence on exposure durations. However, in $\mathrm{Zn}$ exposed fish, the $\mathrm{K}$ and $\mathrm{Cl}$ level showed significant dependence on exposure durations while $\mathrm{Na}$ level depended non-significantly on exposure durations. 
Albumin content in $\mathrm{Ni}$ exposed fish showed significant dependence on exposure duration while in $\mathrm{Zn}$ exposed fish it showed non-significant dependence on exposure duration. Exposure duration dependent increase in the level of glucose and urea was observed. In $\mathrm{Ni}$ and $\mathrm{Zn}$ treated fish urea and glucose level showed significant dependence on exposure durations. Both enzymes level in $\mathrm{Ni}$ and $\mathrm{Zn}$ treated fish showed significant dependence on exposure durations (Table 2).

\section{DISCUSSION}

The presence of toxicants in the aquatic ecosystem exerts toxic effects at cellular and molecular levels which result in significant changes in biochemical composition of the aquatic biota (Chowdhury et al., 2004). The present results are in agreement with the findings of (Oner et al., 2008). They found that $\mathrm{Na}$ and $\mathrm{Cl}$ level was decreased in serum of Oreochromis niloticus although the K level elevated following metals exposure. Levels of $\mathrm{Na}$ and $\mathrm{Cl}$ were also decreased in Cyprinion maleness after exposure to metals (Al-Attar, 2006). Similarly, Grosell et al. (2007) reported the toxic effect of metals on gills function which resulted in loss of $\mathrm{Na}$ ions. The osmoregulatory disturbances induced by metals were associated with an increased epithelial permeability, inhibition of active ions uptake and decrease in the number of active chloride cells (Monteiro et al., 2005). In general, serum $\mathrm{Na}$ and $\mathrm{Cl}$ tend to be similarly affected by waterborne toxicants (McDonald et al., 1989) as observed in present work. Chowdhury et al. (2004) concluded that the increase in $\mathrm{K}$ level probably attributable to stress and acidosis and reflects an efflux of $\mathrm{K}$ from the intracellular compartment of white muscle. Potassium is normally excreted by the kidneys, so disorders that decrease the function of the kidneys can result in hyperkalemia.

Hypoalbuminemia observed in metals treated fish could be due to liver and kidney damage. This is in agreement with Gopal et al. (1997) who stated that every 2-hr analysis of serum total protein level of Cyprinus carpio fish showed an initial sharp increase for varying periods from 2- to 20-hr. After this period a steady decline in serum total protein level was observed over a period of 72-hr metals exposure. Vutukuru (2005) documented the appreciable decline in protein contents of Labeo rohita exposed to metal for 96-hr. Kori et al. (2008) reported the decrease in protein after $\mathrm{Zn}$ exposure. The sub-lethal $\mathrm{Ni}$ exposure resulted in progressive and significant decrease in serum protein with an increase in the duration of exposure time (Mahananda, 2014).
Elghobashy et al. (2001) showed an elevation in serum urea level in fish collected from the lakes and the river Nile. They attributed this increase to the action of metals on the glomerular filtration rate which causes pathological changes in the kidney. Abdel-Tawwab et al. (2011) found an increase in urea level in Nile tilapia under $\mathrm{Zn}$ toxicity which increased with increasing concentration and exposure duration. Al-Zahaby et al. (1998) also found that the exposure of fish to high concentrations of metals led to disintegration of the renal epithelium, shrinkage of glomeruli, breakdown of Bowman's capsule and heavy infiltration by inflammatory cells.

Increase in glucose level is a general response of fish to acute pollutant effects (Ceron et al., 1997). The observed results are in agreement with Firat and Kargin (2010) who reported an increase in serum glucose level of Oreochromis niloticus exposed to different concentrations of $\mathrm{Zn}$ and $\mathrm{Cd}$. An increase in serum glucose level in fish under stress condition was also observed by CiCiK and ENGiN (2005). It was noted that higher concentration of metals caused more severe stress than that of low concentration which leads to further glucose elevation (Hoseini and Hosseini, 2010). An increase in the glucose level in stressed fish makes it clear that the glycogen reserves are being used to meet the stress caused by metals. Depleted glycogen levels under metal stress were observed by CiCiK and ENGiN (2005).

The increase in Ast and Alt level observed in present study is in agreement with Kim and Kang (2004). They observed an increase in serum Ast and Alt concentrations in the Sebastes schlegeli after $\mathrm{Cu}$ exposure with increasing exposure duration. Firat and Kargin (2010) reported an increase in the serum Alt and Ast activities in Oreochromis niloticus exposed to $\mathrm{Zn}$ and $\mathrm{Cd}$ as compared to control. Younis (2012) observed a significant increase in Ast and Alt levels in $\mathrm{Zn}$ treated Oreochromis niloticus with short term exposure. The elevation in the level of these enzymes could be due to variety of conditions, including hepato-pancreatic injury that reflects potential damage to parenchymal cells, muscle, intestinal and hepatic injury (Kandeel, 2004).

\section{CONFLICT OF INTEREST}

The author(s) declare(s) that there is no conflict of interests regarding the publication of this article.

\section{AUTHOR'S CONTRIBUTION}

All authors contributed equally to this research work. 


\section{REFERENCES}

Abdel-Tawwab, M., G. O. El-Sayed and S. Shady. 2011. Acute toxicity of water-born zinc in Nile tilapia, Oreochromis niloticus (L.) fingerlings. Proceedings of the Ninth International Symposium on Tilapia in Aquaculture, Shanghai Ocean Univ. China. p. 44-50.

Al-Attar, A. 2006. The physiological responses of the fish, Cyprinion mhalensis to mercury intoxication. J Egypt Ger Soc Zool A, 51: 123-137.

Al-Attar, A. M. 2007. The Influences of Nickel Exposure on Selected Physiological Parameters and Gill Structure in the Teleost Fish, Oreochromis niloticus. Journal of Biological Sciences, 7: 77-85.

Al-Zahaby, A. S., K. Z. Hemmaid, A. M. Carnal and G. Ghoncmy. 1998. The pollutant effects of copper, zinc and lead on the histological patterns of fish kidney. Egyptian Journal of Aquatic Biology and Fisheries, 2: 15-41.

Association, A. P. H. 2013. APHA. 2005. Standard Methods for the Examination of Water and Wastewater. 21st ed. American Public Health Association, Washington DC, 1220p.

Bernet, D., H. Schmidt, T. Wahli and P. Burkhardt-Holm. 2001. Effluent from a Sewage Treatment Works Causes Changes in Serum Chemistry of Brown Trout (Salmo trutta L.). Ecotoxicology and Environmental Safety, 48: 140-147.

Ceron, J. J., E. Sancho, M. D. Ferrando, C. Gutierrez and E. Andreu. 1997. Changes in carbohydrate metabolism in the eelanguilla anguilla, during short-term exposure to diazinon. Toxicological \& Environmental Chemistry, 60: 201-210.

Chowdhury, M. J., E. F. Pane and C. M. Wood. 2004. Physiological effects of dietary cadmium acclimation and waterborne cadmium challenge in rainbow trout: respiratory, ionoregulatory, and stress parameters. Comparative Biochemistry and Physiology Part C: Toxicology \& Pharmacology, 139: 163-173.

CiCiK, B. and K. ENGiN. 2005. The effects of cadmium on levels of glucose in serum and glycogen reserves in the liver and muscle tissues of Cyprinus carpio (L., 1758). Turkish Journal of Veterinary and Animal Sciences, 29: 113-117.

Doreswamy, K., B. Shrilatha, T. Rajeshkumar and Muralidhara. 2004. Nickel-Induced Oxidative Stress in Testis of Mice: Evidence of DNA Damage and Genotoxic Effects. Journal of Andrology, 25:
996-1003.

Elghobashy, H., K. Zaghloul and M. Metwally. 2001. Effect of some water pollutants on the Nile tilapia, Oreochromis niloticus collected from the river Nile and some Egyptian lakes. Egyptian Journal of Aquatic Biology and Fisheries, 5: 251-279.

Firat, Ö. and F. Kargın. 2010. Biochemical alterations induced by $\mathrm{Zn}$ and $\mathrm{Cd}$ individually or in combination in the serum of Oreochromis niloticus. Fish Physiology and Biochemistry, 36: 647-653.

Gopal, V., S. Parvathy and P. R. Balasubramanian. 1997. Environmental Monitoring and Assessment, 48: 117-124.

Grosell, M., J. Blanchard, K. V. Brix and R. Gerdes. 2007. Physiology is pivotal for interactions between salinity and acute copper toxicity to fish and invertebrates. Aquatic Toxicology, 84: 162-172.

Gupta, V. K., A. Rastogi, V. K. Saini and N. Jain. 2006. Biosorption of copper(II) from aqueous solutions by Spirogyra species. Journal of Colloid and Interface Science, 296: 59-63.

Hoang, T. C., J. R. Tomasso and S. J. Klaine. 2004. Influence of water quality and age on nickel toxicity to fathead minnows (Pimephales promelas). Environmental Toxicology and Chemistry, 23: 86.

Hoseini, S. M. and S. A. Hosseini. 2010. Effect of dietary ltryptophan on osmotic stress tolerance in common carp, Cyprinus carpio, juveniles. Fish Physiology and Biochemistry, 36: 1061-1067.

Jacobson-Kram, D. and K. Keller. 2001. Toxicology Testing Handbook: Principles. Applications and Data interpretation. 2nd Edn., Marcel Decker, New York.

Javed, M., I. Ahmad, N. Usmani and M. Ahmad. 2016. Bioaccumulation, oxidative stress and genotoxicity in fish (Channa punctatus) exposed to a thermal power plant effluent. Ecotoxicology and Environmental Safety, 127: 163-169.

Jee, J.-H., F. Masroor and J.-C. Kang. 2005. Responses of cypermethrin-induced stress in haematological parameters of Korean rockfish, Sebastes schlegeli (Hilgendorf). Aquaculture Research, 36: 898-905.

Kandeel, N. 2004. Toxicological and Metabolic Studies of Some Molluscicides on Harmful Terrestrial Snails (M. Sc. thesis). Zoology Dep., Faculty of Science, Cairo University.

Kim, S.-G. and J.-C. Kang. 2004. Effect of dietary copper exposure on accumulation, growth and hematological parameters of the juvenile rockfish, 
Sebastes schlegeli. Marine Environmental Research, 58: 65-82.

Kori-Siakpere, O., R. Ikomi and M. Ogbe. 2010. Variations in acid phosphatase and alkaline phosphatase activities in the plasma of the African catfish: Clarias gariepinus exposed to sublethal concentrations of potassium permanganate. Asian Journal of Experimental Biological Sciences, 1: 170-174.

Kori, S., Ovie, Ubogu and O. Ewoma. 2008. Sublethal haematological effects of zinc on the freshwater fish, Heteroclarias sp. (Osteichthyes: Clariidae). African Journal of Biotechnology, 7: 2068-2073.

Kousar, S. 2014. Assessment of growth and genotoxicity in peripheral blood erythrocytes of fish exposed to metals toxicity. (Unpublished) thesis, UNIVERSITY OF AGRICULTURE, FAISALABAD PAKISTAN.

Magyarosy, A., R. Laidlaw, R. Kilaas, C. Echer, D. Clark and J. Keasling. 2002. Nickel accumulation and nickel oxalate precipitation by Aspergillus niger. Applied Microbiology and Biotechnology, 59: 382-388.

Mahananda, H. B. 2014. Alterations in some haemato-biochemical parameters of a fresh water, air breathing fish, Channa punctatus (Bloch) under the stress of chronic, sub-lethal dose of nickel. Biolife, 2: 13921397.

McDonald, D. G., J. P. Reader and T. R. K. Dalziel. 1989. The combined effects of $\mathrm{pH}$ and trace metals on fish ionoregulation. Acid Toxicity and Aquatic Animals. Cambridge University Press, p. 221-242.

Monteiro, S. M., J. M. Mancera, A. Fontaínhas-Fernandes and M. Sousa. 2005. Copper induced alterations of biochemical parameters in the gill and plasma of Oreochromis niloticus. Comparative Biochemistry and Physiology Part C: Toxicology \& Pharmacology, 141: 375-383.

N., G. M. and M. P. C. 2010. Diversity of fish fauna from downstream zone of river Mahisagar, Gujarat State, India. Journal of Environmental Sciences, 3: 23-26.

Niyogi, S. and C. M. Wood. 2006. Interaction between dietary calcium supplementation and chronic waterborne zinc exposure in juvenile rainbow trout, Oncorhynchus mykiss. Comparative Biochemistry and Physiology Part C: Toxicology \& Pharmacology, 143: 94-102.

Oner, M., G. Atli and M. Canli. 2008. changes in serum biochemical parameters of freshwater fish Oreochromis niloticus following prolonged metal (Ag, Cd, Cr, Cu, Zn) exposures. Environmental Toxicology and Chemistry, 27: 360.

Palanisamy, P., G. Sasikala, D. Mallikaraj, N. Bhuvaneshwari and G. Natarajan. 2011. Haematological changes of fresh water food fish, Channa striata on exposure to Cleistanthus collinus suicidal plant extract. Research Journal of Pharmaceutical, Biological and Chemical Sciences, 2: 812-816.

Sachar, A. and S. Raina. 2014. Haematological alterations induced by lindane in a fish, Aspidoparia morar. Global Journal of Biology, Agriculture and Health Sciences, 3: 38-42.

Varin, A., A. Larbi, G. V. Dedoussis, S. Kanoni, J. Jajte, L. Rink, D. Monti, M. Malavolta, F. Marcellini, E. Mocchegiani, G. Herbein and T. Fulop. 2008. In vitro and in vivo effects of zinc on cytokine signalling in human $\mathrm{T}$ cells. Experimental Gerontology, 43: 472-482.

Vutukuru, S. 2005. Acute Effects of Hexavalent Chromium on Survival, Oxygen Consumption, Hematological Parameters and Some Biochemical Profiles of the Indian Major Carp, Labeo rohita. International Journal of Environmental Research and Public Health, 2: 456-462.

Vutukuru, S. S. 2003. Chromium Induced Alterations in Some Biochemical Profiles of the Indian Major Carp, Labeo rohita (Hamilton). Bulletin of Environmental Contamination and Toxicology, 70: 118-123.

Younis, E. M. 2012. Hematological and enzymatic responses of Nile tilapia Oreochromis niloticus during short and long term sublethal exposure to zinc. African Journal of Biotechnology, 11. 
Publisher's note: EScience Press remains neutral with regard to jurisdictional claims in published maps and institutional affiliations.

(c) (†)

Open Access This article is licensed under a Creative Commons Attribution 4.0 International License, which permits use, sharing, adaptation, distribution and reproduction in any medium or format, as long as you give appropriate credit to the original author(s) and the source, provide a link to the Creative Commons license and indicate if changes were made. The images or other third-party material in this article are included in the article's Creative Commons license, unless indicated otherwise in a credit line to the material. If material is not included in the article's Creative Commons license and your intended use is not permitted by statutory regulation or exceeds the permitted use, you will need to obtain permission directly from the copyright holder. To view a copy of this license, visit http://creativecommons.org/licenses/by/4.0/.

(C) The Author(s) 2020 . 